\title{
HUBUNGAN KAUSALITAS PASAR SAHAM INDONESIA DENGAN BEBERAPA PASAR SAHAM GLOBAL SAAT TERJADI PANDEMI COVID-19 (PERIODE JANUARI-JUNI 2020)
}

\author{
Johan Trihantoro \\ STIE Unisadhuguna Jakarta, Indonesia \\ Email : johan.ppim@gmail.com
}

\begin{abstract}
Abstrak
Pendahuluan : Pelaku pasar atau investor di awal tahun 2020, dikejutkan adanya wabah corona, virus tersebut berasal dari kota Wuhan Provinsi Hubei, Tiongkok dan menjadi lokasi awal virus corona penyebab Covid-19 terdeteksi pada akhir 2019. Lalu bagaimana dengan pasar saham, tentunya membuat pelaku pasar atau investor terkejut karena informasi pandemi tersebut memiliki tingkat kecepatan informasi baru berpotensi secara langsung dapat mempengaruhi pasar modal sehingga akan berimplikasi katalis negatif pada kinerja nilai saham perusahaan dan indeks bursa saham.

Tujuan : Penelitian ini bertujuan untuk mengidentifikasi apakah ada hubungan sebab akibat antara pasar saham Indonesia dan pasar saham global selama Covid.

Metode : Metode penelitian kuantitatif dan menggunakan data sekunder dan sampel dalam penelitian ini adalah IHSG (Indonesia), Nikkei-225 (Jepang), SHCOM (China), DJA (Amerika Serikat), dan FTSE-100 (Inggris) menggunakan data harian mulai 2 Januari-30 Juni 2020. Model penelitian empiris yang digunakan untuk menguji hipotesis menggunakan Granger Causality.

Hasil : Hasil penelitian menunjukkan bahwa hubungan sebab akibat antara pasar saham Indonesia dengan pasar saham Jepang dan China, hubungan yang terjadi ber independen atau tidak saling mempengaruhi, sementara dengan Amerika Serikat memiliki hubungan arah Uni dan dengan Inggris memiliki hubungan arah BI. Kesimpulan : Penelitian ini memberikan insight yang bertujuan mengindentifikasi apakah ada hubungan kausalitas pasar saham Indonesia dengan pasar saham global saat terjadi Covid-19. Berdasarkan hasil analisis dapat simplukan bahwa adanya peristiwa pandemic covid-19 yang terjadi di awal tahun 2020 memberikan gambaran bagaimana hubungan pasar saham Indonesia dengan pasar saham global saat terjadinya pandemic tersebut.
\end{abstract}

Kata Kunci : Granger Causality, independen, Uni-direction, BI-direction.

\section{Abstract}

Introduction : Market participants or investors in early 2020, shocked by the coronavirus outbreak, the virus originated from the city of Wuhan Hubei Province, China and became the initial location of the coronavirus that causes Covid-19 detected in late 2019. Then what about the stock market, of course, makes market participants or investors surprised because the pandemic information has a new level of information speed can potentially directly affect the capital market so that it will have negative catalysts on the performance of the value of company shares and stock exchange indices.

Purpose : This study aims to identify whether there is a causal relationship between the Indonesian stock market and the global stock market during Covid. 
Hubungan Kausalitas Pasar Saham Indonesia dengan Beberapa Pasar Saham Global Saat Terjadi Pandemi Covid-19 (Periode Januari-Juni 2020)

Methods : Quantitative research methods and using secondary data and samples in this study are JCI (Indonesia), Nikkei-225 (Japan), SHCOM (China), DJA (UNITED STATES), and FTSE-100 (UK) using daily data from January 2 to June 30, 2020. Empirical research models are used to test hypotheses using Granger Causality.

Results : The results showed that the causal relationship between the Indonesian stock market and the Japanese and Chinese stock markets, the relationship that occurred independently or did not affect each other, while with the United States has a relationship direction of the Union and with the United Kingdom has a bi direction relationship.

Conclusion : This study provides insights aimed at identifying whether there is a causality relationship between the Indonesian stock market and the global stock market during Covid-19. Based on the results of the analysis can be found that the covid-19 pandemic event that occurred in early 2020 provides an overview of how the relationship of the Indonesian stock market with the global stock market during the pandemic.

Keywords : Granger Causality, independent, Uni-direction, BI-direction.

\section{Pendahuluan}

Pelaku pasar atau investor di awal tahun 2020, dikejutkan adanya wabah corona, virus tersebut berasal dari kota Wuhan Provinsi Hubei, Tiongkok dan menjadi lokasi awal virus corona penyebab Covid-19 terdeteksi pada akhir 2019 yang menyebabkan pneumonia atau menyerang saluran pernapasan ini menyebar hingga ke seluruh dunia dan Organisasi Kesehatan Dunia yaitu WHO menyatakankan bahwa CoronaVirus Disease-2019 atau Covid-19 sebagai pandemi global. Keberadaan pandemic Covid-19 membuat seluruh negera melakukan kebijakan lockdown sebagai upaya untuk menekan penyebaran virus tersebut. Bahwa COVID-19 memiliki dampak yang luar biasa terhadap perekonomian negara-negara yang terkena dampak (He et al., 2020). Kebijakan tersebut tentunya membuat aktivitas dunia usaha dan masyarakat terbatas sehingga memberikan katalis negatif terhadap kinerja perusahaan dan menurunnya konsumsi rumah tangga yang selanjutnya berdampak pada pertumbuhan ekonomi suatu negara (Saputra \& Harjito, 2015).

Lalu bagaimana dengan pasar saham, tentunya membuat pelaku pasar atau investor terkejut karena informasi pandemi tersebut memiliki tingkat kecepatan informasi baru berpotensi secara langsung dapat mempengaruhi pasar modal sehingga akan berimplikasi katalis negatif pada kinerja nilai saham perusahaan dan indeks bursa saham. Bahwa pergerakan harga saham tergantung pada beberapa faktor yang mencangkup informasi tingkat perusahaan dan tingkat pasar yang tercermin dalam harga saham. Pada pasar keuangan tidak hanya di pengaruhi dari sentimen domestik namun juga terpengaruh dari sentimen perkembangan yang terjadi di pasar keuangan global. Sebelumnya dunia juga pernah mengalami saat krisis subprime mortgage di AS merupakan contoh besarnya pengaruh kejutan eksternal. Krisis keuangan global yang terjadi di Amerika Serikat (AS) telah menyebar ke berbagai belahan dunia dengan 
sangat cepat termasuk ke Indonesia. Krisis di AS yang dikenal sebagai krisis subprime mortgage. Kecepatan penyebaran ini salah satunya didukung oleh struktur pasar keuangan global yang telah terintegrasi dengan baik saat itu. (Longstaff, 2010) bahwa selama tiga tahun terakhir, pasar keuangan telah menderita bencana losses. Hal ini dipicu oleh ancaman default besar-besaran oleh peminjam mortgage. Pada tahun 2008, krisis subprime tumpah dan menjadi katalis untuk krisis keuangan global yang lebih luas.

Semakin terintegrasinya pasar keuangan domestik dengan pasar keuangan global menjadi tantangan yang besar bagi pelaku pasar atau investor (Prio, 2010), sehingga mendorong kebutuhan untuk memahami perkembangan pasar keuangan global dan mengetahui potensi pengaruh perkembangan faktor eksternal (Nasarudin, 2014). Seiring dengan perkembangan jaman, dengan perkembangan dalam globalisasi dan kemajuan teknologi, pelaku pasar dan investor tentunya mempunyai kesempatan dalam diversifikasi asset keuangan atau portfolio tidaknya hanya dilakukan di domestik namun juga dapat dilakukan secara internasional atau antar negera. Diversifikasi internasional tentunya akan memberikan imbal hasil yang diharapkan oleh pelaku pasar dan investor internasional. Janakiraman dan (Janakiramanan \& Lamba, 1998) melakukan penelitian interdependensi antara pasar modal AS dengan pasar modal negara-negara pasifik.

Kesimpulan yang dapat dihasilkan tentang interdependensi pasar saham dapat terjadi karena adanya kekuatan ekonomi yang dominan, kelompok investor yang sama, banyaknya perusahaan yang cross listing dan pengaruh tidak langsung. (Gong et al., 2004) meneliti transmisi krisis keuangan 1997 yang ditransmisikan diantar pasar keuangan negara-negara asia dengan metode VAR, bahwa selama periode krisis lebih signifikan dibandingkan periode non krisis lainnya. Sedangkan (Huyghebaert \& Wang, 2010) (Sukirno \& Sutarmanto, 2007) menemukan bahwa sebelum krisis Asia tahun 1997-1998 pasar modal di Asia Timur kecuali Shanghai dan Shenzen secara umum merespon terhadap kejutan yang bersifat global. Namun fenomena sementara dimana interdependensi yang meningkat pada saat krisis mungkin ditimbulkan oleh adanya market contagion effect.

Metode yang digunakan multivariate VAR. (Glezakos et al., 2007) dalam konteks globalisasi, melalui proses tumbuh integrasi ekonomi diantara negara-negara dan pasar keuangan, keterkaitan antara pasar keuangan utama dunia menjadi lebih dan lebih jelas. Hubungan ketergantungan antara pasar keuangan telah di fokus sejak dekade 1960-an. (Glezakos et al., 2007) juga mengungkapan hasil penelitian Ripley menemukan bahwa ada saling interdependensi tetapi hanya antara negara-negara terbuka untuk investasi modal asing, berbeda dengan pasar yang terisolasi yang tidak menunjukan ketergantungan apapun dengan negara lain.

Selanjutnya, pada penelitian ini memberikan insight mengenai tingkat integrasi pasar modal sehingga pelaku pasar atau investor dapat melakukan diversifikasi secara optimal sehingga memberikan tingkat imbal hasil yang diharapakan. Berdasarkan 
uraian di atas penelitian ini bertujuan mengindentifikasi apakah ada hubungan kausalitas pasar saham Indonesia dengan pasar saham global saat terjadi Covid-19.

\section{Metode Penelitian}

Penelitian ini merupakan penelitaan kuantitatif dan mengunakan data sekunder (Cresswell, 2017). Populasi yang digunakan dalam penelitian adalah indeks komposit saham. Adapun obyek penelitian indeks komposit suatu negara dan sampel dalam penelitian ini adalah IHSG (Indonesia), Nikkei225 (Jepang), SHCOM (Tiongkok), DJA (Amerika Serikat), dan FTSE-100 (Inggris) dengan menggunakan data harian dari tangal 2 Januari-30 Juni 2020 yang diperoleh melalui Bloomberg.

1. Metode Analisis Data

Indeks komposit bursa saham merupakan salah satu indikator utama yang mencerminkan keadaan bursa saham suatu negara (Oktarina, 2016). Dimana indeks tersebut merupakan indicator statistic berupa harga yang menyediakan perwakilan nilai-nilai saham yang membentuknya. Indeks sendiri berfungsi sebagai tolok ukur untuk menilai kinerja investasi yang dimiliki investor. Hubungan kausalitas pasar saham antara beberapa negara dapat dilakukan dengan menguji sejauh mana indeks komposit tersebut mempunya hubungan kausalitas. Untuk menganalisis hal tersebut, perlu dilakukan uji statistic sebegai berikut :

a. Operasional Variabel Penelitian

Dalam penelitian ini mengunakan variabel indek composite bursa saham, yaitu Indeks Harga Saham Gabungan -IHSG (Indonesia), indeks NIKKEI-225 (Jepang), indeks Shanghai Composite-SHCOMT (Tiongkok), Dow Jones Average -DJI (Amerika Serikat) dan FTSE-100 (Inggris).

2. Return Indeks

Dalam penelitian menggunakan data harian indeks pasar saham, selanjutnya peneliti melakukan perhitungan return indek dari setiap variabel operasional yang diteliti, yaitu IHSG, NIKKEI, SHCOM, DJI, FTSE. Perhitungan return indeks menggunakan rumus indeks hari ini $(\mathrm{t})$ dikurangi dengan indeks hasi sebelumnya ( $\mathrm{t}$ 1) kemudian dibagi dengan indeks sebelumnya(t-1).

$$
\mathrm{Rt}=\underline{\mathrm{P}}_{\underline{t}}-\mathrm{P}_{\mathrm{t}-1}
$$

a. Uji Stasioneritas

Data ekonomi time series umumnya bersifat stokastik atau memiliki tren yang tidak stationer, artinya data tersebut memiliki akar unit. Untuk dapat mengstimasi suatu model penggunaan data tersebut langkah pertama yang harus dilakukan adalah pengujian stasioneritas data atau dikenal unit root test (Gujarati \& Porter, 2008) Uji stasioneritas pada penelitian ini menggunakan uji Augmented Dickey-Fuller (ADF) dengan membandingkan nilai absolute statistic terhadap absolut nilai kritis pada table Mac-Kinnon. Data yang tidak stasioner pada ADF 
test selanjutntya dilakukan pembedaan (differencing) pada level pertama atau kedua ADF test agar di dapatkan data yang stasioner.

b. Uji Selang Waktu (lag) Optimal

(Brooks, 2008) dalam uji lag optimal sangat penting, karena panjangnya lag dapat berpenaruh pada stabilitas model dan respon endogen. Dalam menentukan panjang lag optimum, terdapat beberapa kriteria yang dapat dilihat, yaitu Likelihood Ratio (LR), Final Prediction Error (FPE), Akaike Information Criterion (AIC) dan Schwarz Information Criterion (SC) dan Hannan-Quin Criterion $(H Q)$.

c. Uji Granger Causality

Uji kausalitas granger adalah suatu pengujian untuk melihat hubungan kausalitas antar variabel. Secara matematis, untuk melihat apakah $X$ menyebabkan $\mathrm{Y}$ atau tidak. Bila dimisalkan variable $\mathrm{x}$ dan $\mathrm{y}$, dengan melakukan uji granger causality dapat digunakan untuk mengetahui apakah x mempengaruhi $\mathrm{Y}$ atau y mempengaruhi $\mathrm{x}$ (uni-direction causality) dan bila keduanya saling mempengaruhi maka dapat dikatakan bahwa terdapat hubungan bi-direction atau dua arah. (Gujarati \& Porter, 2008) Jenis hubungan kausalitas Granger dapat dibedakan menjadi tiga jenis hubungan yaitu hubungan unidirectional (hubungan satu arah), bilateral (hubungan dua arah), dan independence (tidak ada hubungan kausalitas). Dari hasil pengujian granger causality jika probabilitas F-Stat $<$ alpha maka $\mathrm{H}_{0}$ di tolak.

\section{Hasil dan Pembahasan}

Data yang digunakan dalam penelitian dengan menggunakan data return dari indeks-indeks yang diteliti dengan periode observasi dari bulan Januari sampai dengan Juni 2020. Berikut merupakan statistic deskriptif dari data return indeks yang digunakan dalam penelitian ini.

Tabel 1

Statistik Deskriptif

\begin{tabular}{|c|c|c|c|c|c|}
\hline & R_IHSG & R_NIKKEI & R_SHCOM & R_DJI & R_FTSE \\
\hline Mean & -0.001735 & -0.000256 & $-8.26 \mathrm{E}-05$ & -0.000303 & -0.001291 \\
\hline Median & 0.000000 & 0.000000 & 0.000000 & 0.000404 & 0.000624 \\
\hline Maximum & 0.101907 & 0.080381 & 0.031464 & 0.113650 & 0.090535 \\
\hline Minimum & -0.065787 & -0.060808 & -0.077245 & -0.129265 & -0.108745 \\
\hline Std. Dev. & 0.020245 & 0.020418 & 0.013024 & 0.030775 & 0.022941 \\
\hline Skewness & 0.613992 & 0.419635 & -1.832902 & -0.303346 & -0.736242 \\
\hline Kurtosis & 8.476792 & 5.701548 & 12.19866 & 7.179136 & 7.992221 \\
\hline Jarque-Bera & 169.3296 & 43.01469 & 527.0371 & 95.85372 & 145.6113 \\
\hline Probability & 0.000000 & 0.000000 & 0.000000 & 0.000000 & 0.000000 \\
\hline Sum & -0.223799 & -0.033011 & -0.010650 & -0.039136 & -0.166559 \\
\hline Sum Sq. Dev. & 0.052462 & 0.053362 & 0.021711 & 0.121226 & 0.067366 \\
\hline
\end{tabular}


Pada table 1 dimana sepanjang periode saat terjadi pandemic Covid-19, indeks IHSG, NIKKEI, SHCOM, DJI, dan FTSE memiliki rerata imbal hasil negatif. Diantara indeks-indeks yang dilakukan penelitian indeks IHSG memiliki rerata sebesar $0,1735 \%$, NIKKEI sebesar -0,0256\%, SHCOM sebesar -0,0083\%, DJI sebesar $0,0303 \%$, dan FTSE sebesar $-0,1291 \%$. Indeks IHSG yang merepresentasikan bursa saham Indonesia, terlihat menjadi indeks dengan rerata imbal hasil negatif terbesar dibandingkan dengan indeks-indeks yang ditelit lainnya. Sementara rerata imbal hasil negatif terkecil terlihat pada indeks SHCOM yang merupakan indeks Shanghai Composite. Berdasarkan data deskripti, ini menggambarkan bahwa sepanjang terjadi pandemic Covid-19 untuk periode semester pertama di tahun 2020 kinerja indeks mengalami kontraksi. Terkontraksinya rerata kinerja indeks tersebut hal ini mungkin disebabkan adanya pemicu dari wabah corona yang terjadi di awal tahun 2020 yang direspon negatif oleh pasar. Ini menggambarkan bagaimana sentimen wabah corona menjadi pemicu yang menggerakan pasar saham secara bersamaan (Nurpitasari, 2020). Sehingga dapat ditarik kesimpulan adanya peristiwa pandemic covid-19 yang terjadi di awal tahun 2020 memberikan gambaran bagaimana hubungan pasar saham Indonesia dengan pasar saham global saat terjadinya pandemic tersebut. Kondisi pandemi corona direspon katalis negatif oleh pasar, kondisi tersebut tampaknya menjadi bad news. Hasil penelitian selama pengamatan data menunjukan bahwa pasar saham Indonesia berpotensi lebih mudah rentan terpengaruh dari gejolak pasar. Berdasarkan table 1 menunjukan IHSG memilik rerata imbal hasil negatif terbesar selama periode pengamatan. Sementara dari tabel 2 dapat diketahui tingkat korelasi antar pasar saham, korelasi indeks FTSE dengan DJI memiliki pengamatan korelasi tertinggi di 0.761267 dan korelasi terendah antara indeks NIKKEI terhadap IHSG yang memiliki tingkat korelasi 0.304164 Tabel ini memberikan indikasi adanya intergrasi antar pasar modal beberapa negara di dunia yang selajutnya akan di uji granger causality.

Tabel 2

Korelasi Indeks

\begin{tabular}{cccccc}
\hline \multicolumn{7}{c}{ R_IHSG } & R_NIKKEI & R_SHCOM & R_DJI & R_FTSE \\
\hline \multicolumn{7}{c}{} \\
& & & & \\
\hline R_IHSG & 1.000000 & & & \\
\hline R_NIKKEI & 0.304164 & 1.000000 & & \\
\hline R_SHCOM & 0.353174 & 0.492697 & 1.000000 & \\
\hline R_DJI & 0.363211 & 0.370597 & 0.318568 & 1.000000 & \\
\hline R_FTSE & 0.378320 & 0.489421 & 0.387254 & 0.761267 & 1.000000 \\
\hline \multicolumn{5}{c}{ Sumber: data diolah penulis $(2021)$} \\
\end{tabular}

1. Uji Stasioneritas

Tabel 3

Augmented Dickey-Fuller Test Statistic

\begin{tabular}{ccccc}
$\begin{array}{c}\text { Augmented } \\
\text { Dickey-Fuller }\end{array}$ & $1 \%$ test & $5 \%$ test & $10 \%$ test & \\
Test Statistic & critical value & $\begin{array}{c}10 \\
\text { critical value }\end{array}$ & $\begin{array}{c}\text { critical value } \\
\text { Probabilitas }\end{array}$ & Probal \\
\hline
\end{tabular}




\begin{tabular}{|c|c|c|c|c|c|}
\hline R_IHSG & -9.779654 & -3.482035 & -2.884109 & -2.578884 & 0.0000 \\
\hline R_NIKKEI & -10.05186 & -3.482035 & -2.884109 & -2.578884 & 0.0000 \\
\hline R_SHCOM & -12.74849 & -3.482035 & -2.884109 & -2.578884 & 0.0000 \\
\hline R_DJI & -16.03514 & -3.482035 & -2.884109 & -2.578884 & 0.0000 \\
\hline R_FTSE & -11.71376 & -3.482035 & -2.884109 & -2.578884 & 0.0000 \\
\hline
\end{tabular}

Pada Tabel 3 merupakan uji data stasioneritas dengan menggunakan metode Augmented Dickey-Fuller (ADF). Hasil pengujian tersebut menunjukan pada tingkat semua level menghasilkan yang signifikan sehinnga semua data telah teruji secara stasioner. Pada tabel tersebut terlihat bahwa nilai ADF < dari nilia critical value. Dan nilai probabilitas lebih kecil dari nilai alpha (5\%). Sehingga dapat disimpulkan bahwa semua data telah valid stasioner di level uji, sehingga tidak perlu melakukan differencing pada tingkat satu atau dua.

\section{Penentuan Lag Optimum}

Dari tabel 4 merupakan ringkasan hasil penentuan lag optimum, berdasarkan kriteria FPE, AIC, SC dan HQ maka lag optimal ada di lag 1 sementara berdasarkan kritesia LR lag optimal ada di lag 8. Dari hasil tersebut, peneliti memutuskan untuk menggunakan lag 1. Sehingga lag ini akan digunakan dalam menentukan hubungan kausalitas secara granger terhadap indeks pasar saham.

Tabel 4

Penentuan Lag Optimum

\begin{tabular}{|c|c|c|c|c|c|c|}
\hline Lag & $\log \mathrm{L}$ & LR & FPE & AIC & $\mathrm{SC}$ & HQ \\
\hline 0 & 1576.646 & NA & $3.59 \mathrm{e}-18$ & -25.97763 & -25.86210 & -25.93071 \\
\hline 1 & 1655.974 & 150.7875 & $1.47 \mathrm{e}-18^{*}$ & $-26.87560^{*}$ & $-26.18243 *$ & $-26.59408^{*}$ \\
\hline 2 & 1671.739 & 28.66357 & $1.71 \mathrm{e}-18$ & -26.72295 & -25.45214 & -26.20683 \\
\hline 3 & 1690.482 & 32.53034 & $1.91 \mathrm{e}-18$ & -26.61954 & -24.77109 & -25.86881 \\
\hline 4 & 1715.907 & 42.02430 & $1.91 \mathrm{e}-18$ & -26.62656 & -24.20046 & -25.64123 \\
\hline 5 & 1733.976 & 28.37242 & $2.18 \mathrm{e}-18$ & -26.51200 & -23.50825 & -25.29206 \\
\hline 6 & 1771.174 & 55.33658 & $1.83 \mathrm{e}-18$ & -26.71362 & -23.13224 & -25.25909 \\
\hline 7 & 1795.434 & 34.08363 & $1.91 \mathrm{e}-18$ & -26.70139 & -22.54236 & -25.01225 \\
\hline 8 & 1826.204 & $40.68779 *$ & $1.82 \mathrm{e}-18$ & -26.79676 & -22.06009 & -24.87302 \\
\hline \multicolumn{7}{|c|}{$*$ indicates lag order selected by the criterion } \\
\hline \multicolumn{7}{|c|}{ LR: sequential modified LR test statistic (each test at 5\% level) } \\
\hline \multicolumn{7}{|c|}{ FPE: Final prediction error } \\
\hline \multicolumn{7}{|c|}{ AIC: Akaike information criterion } \\
\hline \multicolumn{7}{|c|}{ SC: Schwarz information criterion } \\
\hline
\end{tabular}

Sumber: data diolah penulis (2021) 
Hubungan Kausalitas Pasar Saham Indonesia dengan Beberapa Pasar Saham Global Saat Terjadi Pandemi Covid-19 (Periode Januari-Juni 2020)

\section{Uji Granger Causality}

Tabel 5 merupakan hasil uji hubungan kausalitas antara indeks pasar saham Indonesia dengan beberapa indeks pasar global lainnya, yaitu ideks IHSG, NIKKEI, SHCOM, DJI, FTSE pada periode Januari-Juli 2020.

4. Hubungan Kausalitas antara Pasar Saham Indoensia dengan Pasar saham Jepang

Hasil uji granger causality menunjukan bahwa hipotesis yang menunjukan bahwa return NIKKEI (R_NIKKEI) menyebabkan secara granger terhadap return (R_IHSG) dengan menggunakan alpha $5 \%, \mathrm{H}_{0}$ diterima dimana probabilitas F-stat $0.1284>0.05$. Dari hasil tersebut dapat ditarik kesimpulan bahwa pasar saham Jepang tidak menyebabkaan secara granger terhadap return pasar saham di Indonesia. Begitu juga dengan R_IHSG dan R_NIKKEI menunjukan nilai

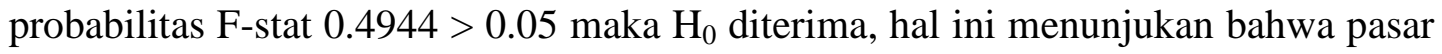
saham Indonesia tidak menyebabkan secara granger terhadap return pasar saham di Jepang. Sehingga hubungan yang terjadi pada kedua pasar saham ini adalah indepeden atau tidak saling mempengaruhi.

5. Hubungan Kausalitas antara Pasar Indonesia dengan Pasar Saham Tiongkok

Hipotesis yang menunjukan bahwa R_SHCOM menyebabkan secara granger terhadap R_IHSG dengan menggunakan alpha $5 \%, \mathrm{H}_{0}$ diterima dimana probabilitas F-stat 0.2212>0.05. Dari hasil tersebut dapat ditarik kesimpulan bahwa pasar saham Tiongkok tidak menyebabkaan secara granger terhadap return pasar saham di Indonesia. Begitu juga dengan R_IHSG dan R_SHCOM menunjukan nilai probabilitas F-stat 0.3302> 0.05 maka $\mathrm{H}_{0}$ diterima, hal ini menunjukan bahwa pasar saham Indonesia tidak menyebabkan secara granger terhadap return pasar saham di Tiongkok. Sehingga hubungan yang terjadi pada kedua pasar saham ini adalah indepeden atau tidak saling mempengaruhi.

6. Hubungan Kausalitas antara Pasar Indonesia dengan Pasar Saham Amerika Serikat

Hipotesis yang menunjukan bahwa R_DJI menyebabkan secara granger terhadap R_IHSG dengan menggunakan alpha $5 \%, \mathrm{H}_{1}$ diterima dimana probabilitas F-stat $00.0038<0.05$. Dari hasil tersebut dapat ditarik kesimpulan bahwa pasar saham Amerika Serikat menyebabkaan secara granger terhadap return pasar saham di Indonesia. Sementara dengan R_IHSG dan R_DJI menunjukan nilai probabilitas Fstat 0. 0.7579> 0.05 maka $\mathrm{H}_{0}$ diterima, hal ini menunjukan bahwa pasar saham Indonesia tidak menyebabkan secara granger terhadap return pasar saham di Amerika Serikat. Sehingga hubungan yang terjadi pada kedua pasar saham ini adalah Uni-direction.

7. Hubungan Kausalitas antara Pasar Saham Indonesia dengan Pasar Saham Inggris

Hipotesis yang menunjukan bahwa R_FTSE menyebabkan secara granger terhadap R_IHSG dengan menggunakan alpha 5\%, $\mathrm{H}_{1}$ diterima dimana probabilitas F-stat $0.0066<0.05$. Dari hasil tersebut dapat ditarik kesimpulan bahwa pasar saham Inggris menyebabkaan secara granger terhadap return pasar saham di Indonesia. Begitu juga dengan R_IHSG dan R_FTSE menunjukan nilai probabilitas F-stat $0.0378<0.05$ maka $\mathrm{H}_{1}$ diterima, hal ini menunjukan bahwa pasar saham Indonesia 
menyebabkan secara granger terhadap return pasar saham di Inggris. Sehingga hubungan yang terjadi pada kedua pasar saham ini adalah Bi-direction.

8. Hubungan Kausalitas antara Pasar Saham Tiongkok dengan Pasar Saham Jepang

Hipotesis yang menunjukan bahwa R_SHCOM menyebabkan secara granger terhadap R_NIKKEI dengan menggunakan alpha 5\%, $\mathrm{H}_{0}$ diterima dimana probabilitas F-stat 0.1821>0.05. Dari hasil tersebut dapat ditarik kesimpulan bahwa pasar saham Tiongkok tidak menyebabkaan secara granger terhadap return pasar saham di Jepang. Begitu juga dengan R_NIKKEI dan R_SHCOM menunjukan nilai probabilitas F-stat 0.1629> 0.05 maka $\mathrm{H}_{0}$ diterima, hal ini menunjukan bahwa pasar saham Jepang tidak menyebabkan secara granger terhadap return pasar saham di Tiongkok. Sehingga hubungan yang terjadi pada kedua pasar saham ini adalah indepeden atau tidak saling mempengaruhi.

Tabel 5

Hasil Uji Granger Causality

\begin{tabular}{|c|c|c|c|}
\hline Null Hypothesis: & $\begin{array}{c}\text { F- } \\
\text { Statistic }\end{array}$ & Prob. & Intrepretasi \\
\hline R_NIKKEI does not Granger Cause R_IHSG & 2.34247 & 0.1284 & \\
\hline R_IHSG does not Granger Cause R_NIKKEI & 0.46974 & 0.4944 & Independen \\
\hline R_SHCOM does not Granger Cause R_IHSG & 1.51176 & 0.2212 & \\
\hline R_IHSG does not Granger Cause R_SHCOM & 0.95564 & 0.3302 & Independen \\
\hline R_DJI does not Granger Cause R_IHSG & 8.68804 & 0.0038 & \\
\hline R_IHSG does not Granger Cause R_DJI & 0.09543 & 0.7579 & Uni-direction \\
\hline R_FTSE does not Granger Cause R_IHSG & 7.64191 & 0.0066 & \\
\hline R_IHSG does not Granger Cause R_FTSE & 4.40855 & 0.0378 & Bi-direction \\
\hline R_SHCOM does not Granger Cause R_NIKKEI & 1.80060 & 0.1821 & \\
\hline R_NIKKEI does not Granger Cause R_SHCOM & 1.97004 & 0.1629 & Independen \\
\hline R_DJI does not Granger Cause R_NIKKEI & 13.3979 & 0.0004 & \\
\hline R_NIKKEI does not Granger Cause R_DJI & 13.8710 & 0.0003 & Bi-direction \\
\hline R_FTSE does not Granger Cause R_NIKKEI & 13.3836 & 0.0004 & \\
\hline R_NIKKEI does not Granger Cause R_FTSE & 10.2999 & 0.0017 & Bi-direction \\
\hline R_DJI does not Granger Cause R_SHCOM & 6.55544 & 0.0116 & \\
\hline R_SHCOM does not Granger Cause R_DJI & 0.47136 & 0.4936 & Uni-direction \\
\hline
\end{tabular}


Hubungan Kausalitas Pasar Saham Indonesia dengan Beberapa Pasar Saham Global Saat Terjadi Pandemi Covid-19 (Periode Januari-Juni 2020)

\begin{tabular}{lccc}
\hline R_FTSE does not Granger Cause R_SHCOM & 4.62020 & 0.0335 & \\
\hline R_SHCOM does not Granger Cause R_FTSE & 2.23537 & 0.1374 & Uni-direction \\
\hline & & & \\
\hline & & & \\
\hline R_FTSE does not Granger Cause R_DJI & 0.00552 & 0.9409 & \\
\hline R_DJI does not Granger Cause R_FTSE & 0.46677 & 0.4957 & Independen \\
\hline
\end{tabular}

Sumber: data diolah penulis (2021) signifikasi level 1\%,5\%,dan $10 \%$

9. Hubungan Kausalitas antara Pasar Saham Amerika Serikat dengan Pasar Saham Jepang

Hipotesis yang menunjukan bahwa R_DJI menyebabkan secara granger terhadap R_NIKKEI dengan menggunakan alpha 5\%, $\mathrm{H}_{1}$ diterima dimana probabilitas F-stat $0.0004<0.05$. Dari hasil tersebut dapat ditarik kesimpulan bahwa pasar saham Amerika Serikat menyebabkaan secara granger terhadap return pasar saham di Inggris. Begitu juga dengan R_FTSE dan R_DJI menunjukan nilai

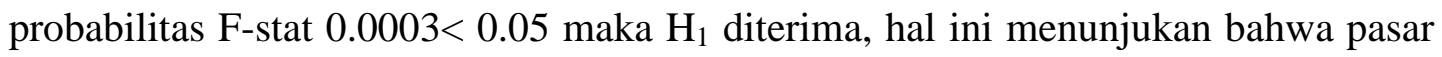
saham Inggris menyebabkan secara granger terhadap return pasar saham di Amerika Serikat. Sehingga hubungan yang terjadi pada kedua pasar saham ini adalah Bidirection.

10. Hubungan Kausalitas antara Pasar Saham Inggris dengan Pasar saham Jepang

Hipotesis yang menunjukan bahwa R_FTSE menyebabkan secara granger terhadap R_NIKKEI dengan menggunakan alpha 5\%, $\mathrm{H}_{1}$ diterima dimana probabilitas F-stat $0.0004<0.05$. Dari hasil tersebut dapat ditarik kesimpulan bahwa pasar saham Inggris menyebabkaan secara granger terhadap return pasar saham di Jepang. Begitu juga dengan R_NIKKEI dan R_FTSE menunjukan nilai probabilitas F-stat $0.0017<0.05$ maka H1 diterima, hal ini menunjukan bahwa pasar saham Jepang menyebabkan secara granger terhadap return pasar saham di Inggris. Sehingga hubungan yang terjadi pada kedua pasar saham ini adalah Bi-direction.

11. Hubungan Kausalitas antara Pasar Saham Amerika Serikat dengan Pasar Saham Tiongkok

Hipotesis yang menunjukan bahwa R_DJI menyebabkan secara granger terhadap R_SHCOM dengan menggunakan alpha 5\%, $\mathrm{H}_{1}$ diterima dimana probabilitas F-stat $0.0116<0.05$. Dari hasil tersebut dapat ditarik kesimpulan bahwa pasar saham Amerika menyebabkaan secara granger terhadap return pasar saham di Tiongkok. Sementara dengan R_SHCOM dan R_DJI menunjukan nilai probabilitas F-stat 0.4936>0.05 maka $\mathrm{H}_{0}$ diterima, hal ini menunjukan bahwa pasar saham Tiongkok tidak menyebabkan secara granger terhadap return pasar saham di Amerika Serikat. Sehingga hubungan yang terjadi pada kedua pasar saham ini adalah Uni-direction.

12. Hubungan Kausalitas antara Pasar Saham Inggris dengan Pasar Saham Tiongkok

Hipotesis yang menunjukan bahwa R_FTSE menyebabkan secara granger terhadap R_SHCOM dengan menggunakan alpha 5\%, $\mathrm{H}_{1}$ diterima dimana probabilitas F-stat $0.03356<0.05$. Dari hasil tersebut dapat ditarik kesimpulan 
bahwa pasar saham Inggris menyebabkaan secara granger terhadap return pasar saham di Tiongkok. Sementara dengan R_SHCOM dan R_FTSE menunjukan nilai probabilitas F-stat 0.1374> 0.05 maka $\mathrm{H}_{0}$ diterima, hal ini menunjukan bahwa pasar saham Tiongkok tidak menyebabkan secara granger terhadap return pasar saham di Inggris. Sehingga hubungan yang terjadi pada kedua pasar saham ini adalah Unidirection.

13. Hubungan Kausalitas antara Pasar Saham Inggris dengan Pasar Saham Amerik Serikat

Hipotesis yang menunjukan bahwa R_FTSE menyebabkan secara granger terhadap R_DJI dengan menggunakan alpha $5 \%, \mathrm{H}_{0}$ diterima dimana probabilitas $\mathrm{F}$ stat 0.9409>0.05. Dari hasil tersebut dapat ditarik kesimpulan bahwa pasar saham Inggris tidak menyebabkaan secara granger terhadap return pasar saham di Amerika Serikat. Begitu juga dengan R_DJI dan R_FTSE menunjukan nilai probabilitas F-stat 0.4957> 0.05 maka H0 diterima, hal ini menunjukan bahwa pasar saham Amerika Serikat tidak menyebabkan secara granger terhadap return pasar saham di Inggris. Sehingga hubungan yang terjadi pada kedua pasar saham ini adalah indepeden atau tidak saling mempengaruhi.

Berdasarkan hasil uji granger tersebut memberikan gambaran, bahwa pasar saham yang mempunyai hubungan independen dapat diartikan bahwa pasar saham tidak saling mempengaruhi, pergerakan pasar saham cenderung terpengaruh dari masing-masing faktor internal. Untuk pasar Uni-direction mengindikasi adanya hubungan searah sehingga dapat diartikan pergerakan pasar saham berhubungan dengan salah satu pasar saham lainnya sehingga pasar saham tidak hanya terpengaruh dari faktor internal tapi juga faktor ekternal. Sementara Bi-direction memberikan indikasi jika kedua pasar mempunyai hubungan dua arah, artiya sentimen setiap yang terjadi pada pasar saham akan mempengaruhi pasar saham lainnya, hal ini munjukan sentimen pengaruh internal dan eksternal saling memberikan hubungan kedua pasar saham tersebut.

$$
\begin{aligned}
& Y t=\sum_{i=1}^{n} \alpha_{i} Y_{t-i}+\sum_{i=1}^{n} \beta_{i} X_{t-i}+e_{1 r} \\
& X t=\sum_{i=1}^{m m} \gamma_{i} X_{t-i}+\sum_{i=1}^{m} \lambda_{i} Y_{t-i}+e_{2 s}
\end{aligned}
$$

\section{Kesimpulan}

Penelitian ini memberikan insight yang bertujuan mengindentifikasi apakah ada hubungan kausalitas pasar saham Indonesia dengan pasar saham global saat terjadi Covid-19. Berdasarkan hasil analisis dapat simplukan bahwa adanya peristiwa pandemic covid-19 yang terjadi di awal tahun 2020 memberikan gambaran bagaimana hubungan pasar saham Indonesia dengan pasar saham global saat terjadinya pandemic tersebut. Kondisi pandemi corona direspon katalis negatif oleh pasar, kondisi tersebut tampaknya menjadi bad news. Hasil penelitian selama pengamatan data menunjukan bahwa pasar saham Indonesia berpotensi lebih mudah rentan terpengaruh dari gejolak pasar, hal in 
tergambarkan rerata imbal hasil pasar saham Indonesia negatif terbesar dibandingkan dengan indeks-indeks yang ditelit lainnya.

Berdasarkan hasil uji granger causality menunjukan bahwa hubungan kausalitas antara pasar saham Indonesia dengan pasar saham Jepang, Tiongkok hubungan yang terjadi pada adalah indepeden atau tidak saling mempengaruhi, sementara dengan Amerika Serikat memiliki hubungan Uni-direction dan dengan Inggris memiliki hubungan Bi-direction. Kausalitas antara pasar saham Tiongkok dan Jepang memiliki hubungan indepeden atau tidak saling mempengaruhi. Kausalitas antara pasar saham Amerika Serikat dan Jepang memiliki hubungan Bi-direction. Kausalitas antara pasar saham Inggris dan Jepang memiliki hubungan Bi-direction. Kausalitas antara pasar saham Amerika Serikat dan Tiongkok memiliki hubungan Uni-direction. Kausalitas antara pasar saham Inggris dan Tiongkok memiliki hubungan Uni-direction. Kausalitas antara pasar saham Inggris dan Amerika Serikat memiliki hubungan indepeden atau tidak saling mempengaruhi.

Untuk penelitian selanjutnya untuk dapat meningkatkan akurasi hasil peneltian dengan memperhitungan hubungan interdependensi pasar saham dengan menggunakan model vector autoregression dan juga menambahkan lebih banyak indeks pasar ke dalam pengujian hipotesis dengan periode waktu yang panjang atau menambahkan dengan variabel indeks MSCI global yang merupakan indeks yang menunjukan performa kinerja pasar modal global serta indeks yang menjadi acuan fund manager.Mutasi dan promosi jabatan berpengaruh positif terhadap komitmen karyawan PT Bank Syariah Mandiri Kantor Wilayah II. Karyawan merasa ada timbal balik yang setimpal dengan apa yang telah mereka berikan ke perusahaan, dengan bentuk promosi jabatan dan mutasi, Sehingga tercipta suatu komitmen rasional yang terbentuk atas dasar pertimbangan untung rugi yang dihadapi karyawan jika berhadapan dengan keputusan untuk tetap bergabung atau hendak keluar dari perusahaan. 


\section{DAFTAR PUSTAKA}

Brooks, C. (2008). RATS Handbook to accompany introductory econometrics for finance. Cambridge Books.

Cresswell, J. W. (2017). Research Design: Pendekatan Kualitatif, Kuantitatif, dan Mixed (Edisi Ketiga). Pustaka Belajar.

Glezakos, M., Merika, A., \& Kaligosfiris, H. (2007). Interdependence of major world stock exchanges: How is the Athens stock exchange affected. International Research Journal of Finance and Economics, 7(1), 24-39.

Gong, S.-C., Lee, T.-P., \& Chen, Y.-M. (2004). Crisis transmission: Some evidence from the Asian financial crisis. International Review of Financial Analysis, 13(4), 463-478.

Gujarati, D., \& Porter, D. (2008). Basic Econometrics, 922 pp. McGraw-Hill, NY.

He, Q., Liu, J., Wang, S., \& Yu, J. (2020). The impact of COVID-19 on stock markets. Economic and Political Studies, 8(3), 275-288.

Huyghebaert, N., \& Wang, L. (2010). The co-movement of stock markets in East Asia: Did the 1997-1998 Asian financial crisis really strengthen stock market integration? China Economic Review, 21(1), 98-112.

Janakiramanan, S., \& Lamba, A. S. (1998). An empirical examination of linkages between Pacific-Basin stock markets. Journal of International Financial Markets, Institutions and Money, 8(2), 155-173.

Longstaff, F. A. (2010). The subprime credit crisis and contagion in financial markets. Journal of Financial Economics, 97(3), 436-450.

Nasarudin, M. I. (2014). Aspek hukum pasar modal Indonesia. Kencana.

Nurpitasari, D. (2020). Analisis Determinasi Harga Saham (Studi Empiris Bank Umum yang terdaftar Di BEI Tahun 2019-2020). Skripsi, Universitas Muhammadiyah Magelang.

Oktarina, D. (2016). Pengaruh beberapa indeks saham global dan indikator makroekonomi terhadap pergerakan IHSG. Journal of Business and Banking, 5(2), $163-182$.

Prio, D. S. (2010). Pengaruh pasar saham dunia dan variabel makroekonomi terhadap ihsg dan lq45. Program Pascasarjana Manajemen Dan Bisnis IPB.

Saputra, R. A., \& Harjito, D. A. (2015). Hubungan Kausalitas Antara Nilai Tukar Dengan Harga Saham Dan Inflasi Di Indonesia. Jurnal Manajemen Dan Bisnis Indonesia, 3(1), 46-60.

Sukirno, R. S. H., \& Sutarmanto, H. (2007). Faktor-faktor yang mempengaruhi intensi membeli produk wayang kulit pada masyarakat suku Jawa. Psikologika: Jurnal Pemikiran Dan Penelitian Psikologi, 12(24), 119-132. 